\title{
How microfinance empowers women in Côte d'Ivoire
}

\author{
Namizata Binaté Fofana - Gerrit Antonides • \\ Anke Niehof • Johan A. C. van Ophem
}

Received: 11 February 2014/ Accepted: 10 January 2015/Published online: 28 January 2015

(C) The Author(s) 2015. This article is published with open access at Springerlink.com

\begin{abstract}
This study deals with the effect of microcredit on women's livelihood and empowerment in rural areas of Côte d'Ivoire. A cross-section survey was conducted among 185 borrowers from two microfinance institutions and 209 nonborrowers in rural areas of Côte d'Ivoire. In addition, a focus group discussion was held with each of the two women groups. After matching the two groups on the probability of obtaining credit, we found that the microcredit group on average had a higher income and a higher value of household assets than the non-borrowers. No differences in the value of personal women's assets were found. Furthermore, on one hand women's decision-making power in the household, as indicated by their strategic gender needs, was positively related to the probability of obtaining microcredit. On the other hand receiving microcredit tended to increase their decisionmaking power.
\end{abstract}

Keywords Microfinance - Household decision making - Empowerment · Propensity score matching

JEL Classification $\quad \mathrm{D} 130 \cdot \mathrm{G} 210 \cdot \mathrm{O} 150 \cdot \mathrm{O} 160$

\footnotetext{
N. Binaté Fofana

Economics and Management Department, Félix Houphouët Boigny (FHB) University, Abidjan-Cocody, 01, BP V34, Abidjan, Ivory Coast

G. Antonides $(\bowtie) \cdot$ A. Niehof · J. A. C. van Ophem

Department of Social Sciences, Wageningen University, Hollandseweg 1, 6706 KN Wageningen,

The Netherlands

e-mail: Gerrit.Antonides@wur.nl
} 


\section{Introduction}

Poverty still exists everywhere in the world. The number of extreme poor in the developing regions was about 1.4 billion in 2008 (UNDP 2012). Despite the fact that some progress in poverty reduction has been made over the last few years, the share of the poor in sub-Saharan Africa remains over $40 \%$ compared to Asia and the Pacific, where the share of the poor fell from $30 \%$ in 1990 to $9 \%$ in 2004 (Ravallion et al. 2007). This study deals with the issue of poverty and the search for strategies to mitigate its effects on household livelihoods in Côte d'Ivoire. A promising strategy is the provision of microfinance as a credit institution for poor people who have no access to a formal bank. Microfinance institutions (henceforth MFIs) enable the poor to undertake income-generating activities to improve their livelihoods and can help them cope with shocks and uncertainties.

Worldwide, women are more likely to be poor than men. Of all people living in extreme poverty in developing countries, an estimated $70 \%$ are women (World Bank 2007). Women are poorer than men because they often lack access to economic resources and opportunities, education and support services, and do not have access to land. Nevertheless, women contribute to the physical work in farm production and support the livelihood of the farm household in many countries (Ellis 2000). Women increasingly take charge of farm activities because of male labour out-migration from rural areas, war, and HIV-related morbidity and mortality, a trend called "feminisation of agriculture" (Cornhiel 2006; FAO 1999, 2005).

Feminisation of agriculture increases the urgency to enhance women's ability to carry out their agricultural and non-agricultural activities and their other household tasks. Microfinance can address this issue by enabling women to generate income and empower them. By empowerment we mean that women's capacity to make meaningful and positive choices is enhanced because of their increased access to resources they can use to exercise their agency (Kabeer 2005; Niehof 2007). Kabeer (2005: 16) refers to this as "transformative forms of agency that do not simply address immediate inequalities but are used to initiate longer-term processes of change in the structures of patriarchy."

Microfinance could be such a resource. However, Bangladesh data (Kabeer 2001; Ali and Niehof 2007) reveal that women's access to microfinance does not necessarily lead to transformative agency but could result in "pseudo-empowerment," where husbands and sons urge their wives and mothers to obtain a loan but saddle them with the burden of repayment and suffering the consequences of default. This implies that it is important that in judging the effectiveness of microfinance for women's empowerment, the intra-household context of gender relations should be taken into account.

Women in Côte d'Ivoire contribute to both food crop and cash crop production. They also dominate the informal sector. However, Ivorian women have achieved little improvement in agricultural productivity and the country is not yet selfsufficient in food production. Women's incomes are low as a consequence of low productivity, caused by a lack of resources to acquire modern inputs or engage in 
new income-generating activities. In this context the state of Côte d'Ivoire is committed to supporting women financially through microfinance.

Microfinance programmes have been promoted since the early 1990s in order to help women to improve their livelihood and that of their families and to positively contribute to the economic growth of the country. However, despite the proliferation of MFI programmes and the fact that it has been more than a decade since they were first implemented, there is little empirical research on the effectiveness of providing loans for the rural population in general and for rural women in particular. Specially, little is known about gender relations within the household in relation to women's access to and the use of microfinance services.

This paper presents a study about women's decision-making power, their control over loans in relation to the gendered intra-household relationships, and the effects of microfinance on their income and wealth. Since we are not aware of any other studies on these issues in Côte d'Ivoire and this is our first study, the results should be considered as exploratory.

\section{Theory}

This section presents an analysis of the state of poverty in Africa and the role of microfinance in poverty reduction. It also deals with the needs of women and how microfinance can help to meet these needs.

\subsection{Microfinance and poverty}

In developing countries, especially in Africa, poverty has the highest prevalence in rural areas, where agricultural production is the key activity (ADB 2000; UNDP 1997). Rural households in general and women in particular face difficulties in generating income from agriculture due to the low level of productivity, which has to do with lack of resources for buying adequate inputs (Whitehead and Kabeer 2002). These constraints prevent the poor from achieving food and livelihood security.

In rural areas, men and women need financial support to invest in agricultural production and non-agricultural income-generating activities such as small trade, food processing, handicraft activities, etc. They may also need credit for consumption, especially during lean periods. However, poor households generally have limited access to formal banks to borrow from. First, because they are not able to provide the collateral required by the banks as they do not own land or cannot prove legal ownership. Second, because the scale of transactions related to their activities is small and therefore results in high transaction costs (Moll 2005).

Other than regular banks, MFIs normally provide comprehensive packages, including small loans, saving facilities, payment services, money transfers and in some cases insurance, to poor and low-income households. MFIs also provide training and information about running a business. By doing so, microfinance is seen as a means to alleviate poverty. By giving financial services to the poor, microfinance may enable them to build up assets, launch new income-generating 
activities or develop their economic activities, participate in a free market economy, smooth their consumption and reduce their vulnerability to risks and external shocks like drought, famine, illness, and floods. Research on poverty and food insufficiency in the U.S. (Leete and Bania 2010) indicates that liquidity constrained households in particular are vulnerable to food insufficiency and that availability of credit could mitigate this effect. By providing these services, MFIs can empower poor people, particularly poor women, and strengthen economic and social structures (ADB 2000; Greeley 2003; Mayoux 1999; Morduch 1999; Rahman 2004; Van Maanen 2004). This explains the commitment of governments, international donors and nongovernmental organisations (NGOs) to support and implement microfinance programmes (Hulme 2000; Mayoux 1999; Simanowitz 2004).

In most countries, women have been the primary target of microfinance initiatives. According to the Microcredit Summit Campaign Report (2005) in a sample of 3,100 programmes, $83.5 \%$ of the clients are women, as are $95 \%$ of Grameen's clients (Armendàriz and Morduch 2005). Women are targeted for many reasons. The first is related to the greater poverty of women than men, particularly in developing countries. Women are poor because often they do not participate in the labour market and because even if they do, any assets they have are controlled by men. Despite their involvement in the agricultural sector as well as their predominance in the informal sector, many women especially in rural Sub-Saharan Africa areas still achieve only low productivity, as they lack resources (Whitehead and Kabeer 2002). So, providing financial services for women may enable them to carry out income-generating activities and increase their productivity and income. Evidence from respectively Bangladesh and from the summary of the results of an evaluation by IFPRI suggests that loans to women result in meeting social goals like improving household food consumption, health and education (Khandker 2003; Skoufias 2001).

The second reason for lending money to women is financial. Studies conducted in Malawi, Bangladesh, Indonesia and Nigeria showed that women generally seem to be more credit-worthy than men because they have a better repayment record and are recognised for their dynamism, hard work, skills and entrepreneurial spirit (Hulme 1991; Khandker et al. 1995; Niehof 2007; Udong et al. 2010). Moreover, women use money for the benefit of the household, especially their children, whereas men are considered as tempted to use their earnings more to satisfy their own needs instead of investing it in business or using it to improve their household's welfare (FAO 2000). Additionally, Armendàriz and Morduch (2005) pointed out that women tend to be less mobile and more at home than men. This is an advantage for MFIs because it becomes easier and less costly for MFI managers to monitor them. Also for group borrowing it is important that the female members work in each other's proximity.

The general enthusiasm about microfinance should not obscure the fact that, despite its potential, the effects of microfinance on poverty remain contested. Based on the results of their study in seven developing countries, Hulme and Mosley (1996) concluded that microfinance interventions were ineffective in reducing poverty among the very poor. Chua et al. (2000) found that the lending outreach of MFIs to poor borrowers is limited and then argued that this limited participation of 
the poor is proof that the programme failed to alleviate poverty. A study in Malawi (Diagne 1998) showed that microfinance programmes resulted in a decrease in households' net crop income and food consumption. Access to credit had led farmers to respond to an increase in input prices by borrowing rather than changing their farming strategies. Rahman (1999) found that women in Bangladesh used their savings and household assets for consumption and that they diverted loans for consumption needs or used new loans to pay instalments. According to Armendàriz and Roome (2008), the exclusion of men from access to subsidised finance may create friction and cause backlash effects that diminish the supportive role of women in their households regarding the provision of health and education. They call it the women-disempowering effect. Goetz and Gupta (1996) also found that borrowers of rural credit programme in Bangladesh diverted their loans for consumption or to repay their old loans. Other research yielded similar findings (Buckley 1997; Johnson and Kidder 1999; Kabeer 2001; Mayoux 1999; White and Robinson 2000). In some cases, as indicated in the study done by Coleman (2006) in Thailand, the MFI programmes do not reach the poor as much as the relatively wealthy. In addition, women borrowers may be subject to group pressure, resulting in intimidation and violence against them (Karim 2001). Finally, a loan becomes a debt, and the poor have no source of income to repay their loans (Rogaly 1996). Accordingly, Amin et al. (2003) concluded that the vulnerable poor borrowers of MFIs were further impoverished.

Other studies have found positive effects on poverty alleviation. According to Pitt and Khandker (1998) microfinance programmes in Bangladesh contribute to an increase in women's independent income and a net increase in household consumption. They also found that the marginal effect of the size of MFI loan on consumption was $18 \%$ for women and $11 \%$ for men and that there was a strong effect on schooling of girls due to women's participation in MFIs. Sebstad and Chen (1996) found an increase of 25-40\% in enterprise earnings and household income as a result of access to loans. Hulme and Mosley (1996) and Mosley (2001) found that the incomes of poor borrowers had increased more than the incomes of the control group (non-borrowers). Chua et al. (2000) concluded that microfinance services helped clients build up all kinds of assets, and also enabled them to diversify their sources of income. Several studies suggest that lending to women does improve household incomes and leads to other benefits like increased livelihood diversification, more market activity, more education and better health (Morduch and Haley 2002; Mosley and Rock 2004; Todd 1996; Zaman 2004).

\subsection{Gender needs and microfinance}

Both within households and in society at large, men and women have different needs because of their gender roles and they have unequal control over resources (Moser 1993). Moser (1989, 1993) defined two types of women's needs: practical gender needs (PGN) and strategic gender needs (SGN). The first refers to the needs that result from the concrete conditions women experience in society in terms of reproductive work (childbearing and child care, cooking, cleaning, fetching firewood, carrying water, etc.), productive work (production of food and cash crops or generating income 
by food processing, craft work, or trade), and community activities. If women's PGN are met, for example by good access to water sources, household welfare is enhanced. SGN address fundamental relationships between men and women regarding the division of labour, decision-making power, control over resources, subordination of women and political rights. They are also related to women's lack of resources, low level of education, and poverty risk compared to that of men (Molyneux 1985). The two sets of needs are different but related. While better meeting PGN may have no effect on meeting SGN, empowering women by meeting their SGN increases their decision-making power which they can use to help meeting their practical needs as women. For example, to ensure rural households' better access to improved water sources (PGN) women need to have an active voice in the design and management of rural water schemes (SGN) (cf. Cleaver and Hamada 2010). Being empowered, women can achieve greater equality, change their existing roles and challenge their subordinate position (Kabeer 2001). By giving financial support to women's activities, MFIs can strengthen women's fall-back position and bargaining power, thereby addressing both their practical and strategic gender needs (ADB 2000; Goetz and Gupta 1996; Mayoux 1999). However, little is known about how by supporting women's business activities, microfinance programmes can in fact help women to meet their household responsibilities as well as improve their power position within the household and beyond.

Holvoet (2005) found in her research in South India that membership in women's groups shifts overall decision-making patterns from norm-guided behaviour and male decision making to more joint and female decision making. Armendàriz and Roome (2008) found that providing women with MFI loans can result in higher income in the hands of women which might be used in health improvement and education of the women and their children. They call this the women empowering effect. Furthermore, women's gain in decision-making power within the household may increase their chance to obtain MFI credit.

However, studies have also argued that income earning does not always lead to the improvement of women's bargaining power in the household. For example, using evidence from Mexico, Gonzales de la Rocha (1994) and Laier (1997) argued that this situation may happen when women do not control household resources and their wages for cultural and ideological reasons, i.e. that women are subordinated to their husbands (Ali and Niehof 2007). Likewise, Garikipati (2008) found in India that lending to women is likely to strengthen the household's ability to cope with vulnerability across income groups but that the women themselves, especially the poorest ones, are not likely to see consistent improvements in their household status. Evidence from Bangladesh (Goetz and Gupta 1996) suggests that microfinance does not increase women's bargaining power entirely because on average women borrowers surrender nearly $40 \%$ of their control over the investment decisions they make to their husbands. More alarmingly, over $90 \%$ of the returns these women realise from their investments are handled by their husbands. Hence, income gained by women does not always lead to their empowerment. Factors other than income may have an influence on women's decision-making power within the household.

In this study, we hypothesize that women with MFI credit have more income and wealth, and more power in household decision making, indicating that strategic 
gender needs (SGN) are better met, than women without MFI credit. Furthermore, women who have obtained MFI credit have more power (SGN) in household decision-making than before taking credit. As the fulfilment of practical gender needs is only indirectly accomplished, via meeting strategic gender needs, we have no hypothesis on the effect of microcredit on PGN. In turn, power in household decision-making increases the chances of obtaining MFI credit.

\section{Methods}

\subsection{Study area and MFI coverage}

This study was conducted in Abengourou located in the Central Eastern region of Côte d'Ivoire. The region of Abengourou occupies a surface area of 5,200 $\mathrm{km}^{2}$ and has a population of about 288,200 (INS 2008). The Agni are the dominant ethnic group in the area. Among the Agni a matrilineal kinship system prevails. However, women cannot directly inherit land. Land is passed on through male maternal descendants. Land is male property that is inherited by nephews from their maternal uncle. Hence, women by themselves have no direct access to land. Married women are allowed to use their husband's land for the house-hold's agricultural production, but they cannot claim rights on land as an asset (Binaté Fofana 2010). During the 1980s, the Abengourou region was the leading producer of coffee and cocoa, the most important export products of the country. The region is still one of the main agricultural production regions, with coffee, cocoa and staple crops as the core products. Women are the main producers of staple crops (cassava, maize, plantain, peanut) and horticultural crops (peanut, eggplant, hot pepper, okra, tomato, etc.), while men are engaged in cash crop production (mostly coffee and cocoa). In addition, women are engaged in the trade of agricultural products and nonagricultural goods of which they control the proceeds.

Microfinance institutions (MFIs) are present and contribute to the development of the region, in particular the National Union of Credit and Saving Cooperatives of Côte d'Ivoire (COOPEC), and the Mutual Savings and Credit Network (CMEC). These two MFIs have been selected for inclusion in this study because they are the most important microfinance institutions in the country and are the sole microfinance institutions in the study area. COOPEC has set up a special credit programme for women, called Women Access to Financial Services (AFISEF), which gives technical and managerial support to female borrowers. In contrast to COOPEC, the services provided by CMEC for women are limited to credit. However, CMEC provides group lending, in addition to individual loans.

\subsection{Sample and data collection methods}

A cross-sectional survey among women was conducted in 2006. In addition qualitative research was done to gain understanding about the socio-cultural factors affecting women's decision-making power and control over the use of loans. 
The study's units of analysis were women who borrowed money from microfinance institutions. For a proper assessment of the effects of microfinance on women's livelihoods, the study also included female non-borrowers as a control group. Finally, the microfinance institutions (COOPEC and CMEC) formed a different type of research unit, studied in order to understand their functioning and the extent to which they were achieving their goal of poverty alleviation.

The study sample comprised a total number of 185 adult women who had borrowed money either from COOPEC (95 women) or CMEC (90 women) and who were engaged in agricultural or non-agricultural activities. The control group (without MFI credit) consisted of 209 adult women who were also engaged in agricultural or non-agricultural activities. Multi-stage sampling was used to select the study sample: first, village sampling and, second, sampling of the women within the villages. Three villages (Appronpron, Sankadiokro and Amélékia) were selected from a list of twelve with CMEC presence. The reason for selecting only three villages out of twelve where CMEC is present is primarily that before the fieldwork period some CMEC institutions were not functioning well due to a high level of default. For COOPEC, two out of four villages were selected (Zaranou and Ebilassokro). In the other two villages, COOPEC activities were just set up, so the period of loan provision was too short to conduct the survey. Within the selected villages, the respondents were randomly selected. A written questionnaire was used to collect empirical data through face-to-face interviews.

Although there may be larger samples used in some other studies, the sample size of our exploratory study of 394 respondents is in line with those of several other studies in this field, including Bauer et al. (2012, N = 573), Garikipati (2008, $\mathrm{N}=291)$, Goetz and Gupta $(1996, \mathrm{~N}=275)$, Holvoet $(2005, \mathrm{~N}=300)$, Kremer et al. (2013, $\mathrm{N}=188)$, McIntosh (2008, $\mathrm{N}=380)$, Rahman (1999, $\mathrm{N}=295)$ and Tedeschi (2008, $\mathrm{N}=393)$.

Focus group discussions (FGD) were conducted with two groups of women involved in this study: those who had obtained credit (FGD1) and those who had not (FGD2). FGD is a method used to collect qualitative data from a small group of people. It was used in this study to get insightful information about women's perceptions of: (a) credit (both individual and group lending) in terms of its utility and effectiveness; (b) household labour allocation, and women's decision-making power with respect to their needs; (c) importance of MFIs; (d) use of loans and income.

\subsection{Measures}

The objective of this section is to show how we measured women's empowerment and assessed the impact of microfinance. To do so, we used exploratory factor analysis and propensity score matching, respectively. These two methods are described below.

\subsubsection{Exploratory factor analysis}

Within a household, a woman's decision-making power to manage her livelihood is associated with her being able to choose the type of activity she wants to carry out, 
to freely decide whether to borrow money or not, and to have control over her own income (cf. Kabeer 2001). To assess women's empowerment, we used women's decision-making power as a proxy. Since the scale items for decision-making power were never used before, principal components analysis was conducted as an exploratory factor analysis (EFA) to select the factors representing women's decision-making power. EFA is considered an appropriate technique to analyse new measures (Conway and Huffcutt 2003). In the EFA, we do not take into account heterogeneity of the samples with and without credit. The degree of influence on household decision-making was measured by ten survey items which were rated on a 3-point scale ( $1=$ My husband and relatives, $2=$ My husband and myself, 3 = Myself). For each item, the information was collected on the basis of women's subjective response referring to the situation before credit-taking. Data on empowerment before taking credit was collected by retrospective questions. In addition, socio-demographic information was gathered, including household composition, marriage status, education, ethnicity, female monthly net income, total female assets, and total household assets.

\subsubsection{Microfinance impact assessment}

Our impact assessment seeks to address the question of how participants would have performed in the absence of an MFI programme or how non-participants would have performed had they participated in the programme. The main problem here is how to prove that the changes observed in the outcomes can be attributed to microfinance credit. Characteristics of individuals prior to the participation may cause self-selection bias, and also the kind of programme intervention and the environment may lead to programme placement bias and shape intervention outcomes (Pitt and Khandker 1998; Sebstad and Chen 1996). Self-selection occurs because of initial differences in characteristics of borrowers and non-borrowers, i.e., heterogeneity. For example, female borrowers may have initial entrepreneurial ability compared to non-borrowers that may enable them to earn a higher income, even in the absence of MFI credit. Or borrowers may be better off compared to nonborrowers, especially when access to credit depends on the availability of savings. So, female borrowers are those who can contribute savings, while those who have no savings may not participate. The difference in outcomes may also be due to certain characteristics of MFIs, for example the way they design their credit programmes. In such a situation, the credit status of women is not randomly distributed and comparing the mean outcomes of borrowers and non-borrowers will be subject to bias. Thus, before assessing the impact of MFI credit we first need to make the two groups comparable.

Different methods have been used to assess the impact of microfinance credit on the borrowers. One of the simple and widely used methods in the microfinance literature is to compare programme participants (the treated group) to nonparticipants (control group) on key outcomes that are expected to be affected by participation. However, this method has been criticised (Todd 2008) for ignoring the selection problem. Another method recently used in impact assessment is propensity score matching (PSM), which aims at reducing the selection bias. We used it in our 
study to assess the effects of MFI credit on women with respect to a number of relevant variables. The method is described below.

\subsubsection{Propensity score matching (PSM)}

Propensity score matching (PSM) is defined as the conditional probability of receiving treatment given pre-treatment or exogenous individual characteristics (Rosenbaum and Rubin 1983). In our case we can define PSM as the conditional probability of a woman obtaining credit from MFIs given certain characteristics such as age, education level, marital status, ethnicity, etc. The PSM method is a widely used non-experimental method of evaluation in economic policy that can be implemented to estimate the average effect of a treatment or programme intervention (Todd 2008). It helps to adjust initial differences between the treated and control group by matching participants and controls with similar propensity scores based on observable characteristics. After the adjustment, any difference in the outcomes between the two groups can be attributed to the programme or treatment.

Two main assumptions underlie the PSM method. The first is that the selected exogenous variables simultaneously affect participation and outcomes but are not influenced by participation in the treatment. The second is that individuals from the treatment and control groups are comparable before the treatment. According to Heckman (1979) the latter condition ensures that individuals with the same observable characteristics have a positive probability of being in both treatment and control groups. The average treatment effect on the treated group is the difference between the mean outcomes for matched treated and untreated individuals.

The estimation of the average treatment effect using the PSM method is done step-wise. First, a propensity score capturing the probability of being treated given a set of exogenous characteristics is estimated for each group using a probit regression. Second, individuals are matched on the basis of their predicted probabilities of participation. Since the probability of observing two observations with exactly the same value of the propensity score is in principle zero, different methods are used by which weights are given for matching precision. Here, we use Kernel Matching (KM), in which all control cases are matched to each treated case but weighted such that those closest to the treatment case are given the largest weight. According to Tesfay (2009), KM has the advantage of ensuring low variance because it uses the weighted average of all individuals in the control group to construct the counterfactual outcome. To ensure comparability once propensity scores are estimated and cases are matched, the third step is conducting a $t$ test for differences in pre-treatment variables between control and treated groups.

To construct a propensity score based on the probability of obtaining MFI credit, we used the woman's age, her type of activity, wealth, ethnicity, level of education and marital status, household size, gender of household head, and decision-making power within household. These variables are expected to simultaneously influence the probability of a woman obtaining a loan and the outcomes. The outcomes to be measured as the effects of microcredit are women's net income and assets, and household assets, to be described next. 
3.3.3.1 Income Net income represents the total amount of money earned per month from agricultural and/or trade activities of women. The monthly time period has been chosen to compare income of traders who make money every day, with farmers who earn money per season by selling crops after the harvest.

3.3.3.2 Assets Assets are the basic factors of production, consumption and investments that are controlled and accessed by the household. The value of assets is represented by the sum of monetary values (in francs CFA, local currency) of livestock, equipment, electric appliances and consumer goods that belong to the household. Several studies have found that the provision of loans for women may enable them to build up and improve the value of their assets (ADB 2000; Mayoux 1999; Rahman 2004; Van Maanen 2004).

\section{Results}

\subsection{Decision-making power}

For the before-MFI credit situation, the factor analysis yielded two factors that explained 43 and $21 \%$ of the item variance, respectively. The items which loaded highly on the first factor concerned women's participation in decision making in terms of the use of household consumption goods and household income, household expenditure on equipment, schooling of children, and the participation of women in community activities. This factor was interpreted as a practical gender needs factor (PGN). The second factor encompassed women's decision making in terms of borrowing money, trading goods, and the use of women's income. This factor was associated with women's own business activities reflecting the women's strategic gender needs (SGN). In Table 5 of the "Appendix" the relevant items are underlined. The Cronbach's alpha reliability coefficient for PGN was 0.88 , for SGN it was 0.70 . Next, the average of the relevant items was calculated for each factor, both before and after taking credit.

The results of a $t$ test (Table 1) indicates significant differences between the two situations with respect to the power in decision making related to both SGN $(p<0.001)$ and PGN $(p<0.001)$. The results suggest that receiving MFI credit has resulted in more practical and strategic decision-making power of female borrowers. Indeed, with the increase in the income they earned from their activities, women borrowers were able to reinforce their fall-back position. This has led to an

Table 1 Women's decision-making power before and after obtaining credit

\begin{tabular}{lllllll}
\hline & \multicolumn{2}{l}{ Before obtaining MFI credit } & & \multicolumn{2}{l}{ After obtaining MFI credit } & $t$ \\
\cline { 2 - 3 } & Mean & SE & & Mean & SE & $5.529 *$ \\
\hline Practical gender needs & 2.216 & 0.052 & & 2.336 & 0.048 & $3.837^{*}$ \\
Strategic gender needs & 2.800 & 0.032 & & 2.892 & 0.019 & 3.9 \\
\hline
\end{tabular}

$* p<0.001 ; N=185$ 
improvement in the women's power in decision making regarding gender needs, meaning that women are more likely to make their own decisions about what types of goods to produce and sell, and, more importantly, they could decide how to use their loans and their income. Meeting strategic gender needs amounts to empowerment. It is important for women because it affects the profit they can make from the MFI services provided for them which, additionally, has a positive effect on the capability of the credit institutions to financially support women.

It has to be noted that women's responses to retrospective questions used to compare decision-making power before and after obtaining MFIs credit, are subject to recall bias or hindsight bias. ${ }^{1}$ This would lead to a smaller difference between the situations before and after obtaining MFI credit. However, our result showed a significant difference in gender need variables between the two situations.

\subsection{Results of MFI empowerment}

\subsubsection{Socio-demographic characteristics}

Table 2 shows the socio-demographic characteristics of women who have obtained MFI credit and women without MFI credit. It shows both the unmatched and matched variable means. From the unmatched sample, we can conclude that women who obtained MFI credit are likely to be adult Agni female household heads with few household members. They have more power in decision making within the household than women without credit. In the matched sample there is no significant difference between the two groups of women with respect to the variables in the table. This means that the bias of having women with and without credit was reduced and that, therefore, the treatment and the control groups are now comparable on the basis of the selected pre-treatment characteristics.

\subsubsection{Factors explaining women's access to MFI credit}

Table 3 shows the estimated probit regression model for obtaining microcredit. It indicates that Agni women and those who have more power in decision-making are more likely to obtain credit. Agni is the principal ethnic group in the study area, and this fact may give Agni women a better chance to be well informed about the services offered by MFI, as most of the MFI agents in the region belong to this group. There may be a positive discrimination in favour of Agni women in the process of credit provision as reported during the focus group discussion. Decision-making power in terms of SGN is positively linked to obtaining MFI credit. Women with more power in decision-making, have more chance to obtain MFI credit. As explained above, when a woman has power within the household, she can efficiently invest her money and make a profit. MFIs will therefore prefer such a woman in whom they will have more confidence. As predicted, women with a large household size are less likely to obtain

\footnotetext{
1 Hindsight bias refers to the tendency people have to view events as more predictable than they really are. People often recall their predictions before the event as much stronger than they actually were. With hindsight people consistently exaggerate what could have been anticipated with foresight (Fischhoff 1980).
} 
Table 2 Socio-demographic characteristics of women with and without MFI credit

\begin{tabular}{|c|c|c|c|c|c|c|}
\hline & \multicolumn{2}{|c|}{ Unmatched samples } & \multirow[t]{2}{*}{$t$} & \multicolumn{2}{|c|}{ Matched samples } & \multirow[t]{2}{*}{$t$} \\
\hline & $\begin{array}{l}\text { Women with } \\
\text { credit } \\
(\mathrm{N}=185)\end{array}$ & $\begin{array}{l}\text { Women without } \\
\text { credit } \\
(N=209)\end{array}$ & & $\begin{array}{l}\text { Women with } \\
\text { credit } \\
(\mathrm{N}=137)\end{array}$ & $\begin{array}{l}\text { Women without } \\
\text { credit } \\
(\mathrm{N}=179)\end{array}$ & \\
\hline Age in years & 42.21 & 39.46 & $2.31 *$ & 41.2 & 41.3 & 0.10 \\
\hline Household size & 5.47 & 6.15 & $2.67 * *$ & 5.41 & 5.62 & 0.69 \\
\hline $\begin{array}{l}\text { Female } \\
\text { household } \\
\text { head }^{\text {a }}\end{array}$ & 0.43 & 0.27 & $3.36^{* *}$ & 0.41 & 0.40 & 0.25 \\
\hline $\begin{array}{l}\text { Married woman } \\
\text { (dummy) }\end{array}$ & 0.61 & 0.64 & 0.73 & 0.64 & 0.64 & 0.05 \\
\hline $\begin{array}{l}\text { Primary } \\
\text { education } \\
\text { (dummy) }^{\mathrm{c}}\end{array}$ & 0.44 & 0.45 & 0.33 & 0.44 & 0.50 & 0.95 \\
\hline $\begin{array}{l}\text { Decision- } \\
\text { making power } \\
\text { (SGN) }\end{array}$ & 0.13 & -0.21 & $3.32 * *$ & -0.01 & -0.04 & 0.25 \\
\hline $\begin{array}{l}\text { Decision- } \\
\text { making power } \\
\text { (PGN) }\end{array}$ & -0.08 & 0.16 & $2.32 *$ & -0.05 & -0.04 & 0.11 \\
\hline Ethnicity: Agni ${ }^{\mathrm{d}}$ & 0.91 & 0.66 & $6.23 * *$ & 0.90 & 0.92 & 0.66 \\
\hline
\end{tabular}

$* p<0.05 ; * * p<0.01$

Reference categories ${ }^{\mathrm{a}}$ male household head, ${ }^{\mathrm{b}}$ single, ${ }^{\mathrm{c}}$ illiterate, ${ }^{\mathrm{d}}$ other ethnic groups

Table 3 Probit model of obtaining MFI credit

\begin{tabular}{|c|c|c|}
\hline & \multicolumn{2}{|c|}{ Probability of obtaining MFI credit } \\
\hline & Coefficient & $Z$ \\
\hline Age & 0.034 & 0.87 \\
\hline Age squared & -0.0003 & 0.69 \\
\hline Household size & -0.073 & $2.25^{*}$ \\
\hline Female household head $^{\mathrm{a}}$ & 0.388 & 1.83 \\
\hline Power of decision-making (SGN) & 0.314 & $3.47 * *$ \\
\hline Power of decision-making (PGN) & 0.038 & 0.35 \\
\hline Married woman (dummy) ${ }^{\mathrm{b}}$ & 0.377 & 1.86 \\
\hline Primary education (dummy) ${ }^{\mathrm{c}}$ & -0.201 & 1.24 \\
\hline Ethnicity: Agni (dummy) ${ }^{\mathrm{d}}$ & 1.058 & $5.09 * *$ \\
\hline Constant term & -1.683 & $1.96^{*}$ \\
\hline
\end{tabular}

$* p<0.05 ; * * p<0.01$

Reference categories ${ }^{\mathrm{a}}$ male household head, ${ }^{\mathrm{b}}$ single, ${ }^{\mathrm{c}}$ illiterate, ${ }^{\mathrm{d}}$ other ethnic groups

MFI credit. The same holds true for married women and female household heads. Contrary to what we expected, neither the level of education nor age was significant. Hence, in our study, these two variables did not affect or explain MFI credit taking. 
Table 4 Average effects of obtaining MFI credit on a set of outcomes

\begin{tabular}{|c|c|c|c|c|c|c|c|c|}
\hline & \multicolumn{3}{|c|}{ Unmatched } & \multirow[t]{2}{*}{$t$} & \multicolumn{3}{|l|}{ Matched } & \multirow[t]{2}{*}{$t$} \\
\hline & $\begin{array}{l}\text { With } \\
\text { credit }\end{array}$ & $\begin{array}{l}\text { Without } \\
\text { credit }\end{array}$ & Diff. & & $\begin{array}{l}\text { With } \\
\text { credit }\end{array}$ & $\begin{array}{l}\text { Without } \\
\text { credit }\end{array}$ & Diff. & \\
\hline $\begin{array}{l}\text { Income in FCFA/ } \\
\text { month }\end{array}$ & 50,179 & 29,331 & 20,448 & $4.53 * *$ & 49,648 & 31,964 & 17,684 & $3.27 * *$ \\
\hline $\begin{array}{l}\text { Women's assets } \\
\text { (FCFA) }\end{array}$ & 39,807 & 21,880 & 17,927 & 1.49 & 41,662 & 25,667 & 15,995 & 1.20 \\
\hline $\begin{array}{l}\text { Household assets } \\
\text { (FCFA) }\end{array}$ & 552,312 & 312,721 & 239,591 & $2.15^{*}$ & 431,465 & 249,839 & 181,626 & $3.07 * *$ \\
\hline
\end{tabular}

FCFA Francs Communauté Financière Africaine (African Franc)

$* p<0.05 ; * * p<0.01$

\subsubsection{Effects of MFI credit on income and assets}

The effects of MFI credit, after controlling for potential bias, are shown in Table 4. These effects are the differences in outcomes between the groups of women with and without MFI credit, respectively. A positive difference for a particular outcome means that participation in MFI credit has led to a positive change in that particular outcome that can be attributed to receiving MFI credit. The results indicate that the difference in income between matched groups of women who received MFI credit and women without MFI credit is positive. This means that female borrowers on average earned more income than non-borrowers. Thus, we can say that MFI credit has helped women to improve the level of their income. Furthermore, the table shows that after propensity score matching, the value of women's assets did not significantly differ between the two groups but a positive difference in the value of household assets was found. This result shows that female borrowers use their income for buying household assets (e.g., bed, chair, hoe, radio set) rather than goods for themselves (e.g., clothing, jewellery). Since women lack control over the household's land size and land use, they would not be inclined to invest their own income in land and agriculture. Thus, participation in MFI credit resulted in an increase in the value of household assets. This was corroborated by the focus group discussion in which women reported that their main objective for taking credit was to contribute to household livelihood and consumption and to be able to take care of their children.

\section{Conclusion}

The results indicated that MFIs that manage loan repayments properly are likely to be effective in enhancing women's income. However, access and use of MFI credit in rural areas did not significantly increase the value of women's assets although it did significantly enhance the value of household assets. These results differ from the finding of several studies that the provision of credit enables women to build up and improve the value of their assets (Mayoux 1999; Rahman 2004; Van Maanen 2004). First, an individual or household with access to credit is more likely to earn income. 
Second, higher income enables women to build up their assets. Although this paper provides evidence of the positive relationship between MFI credit and women's income, it also reveals that female borrowers were more likely to use their earned income to improve the household's standard of living than to build up their own assets. However, this could strengthen their bargaining position in the household (Agarwal 1997) and, if so, would be a form of "transformative agency" or empowerment (Kabeer 2005). This idea is consistent with research among German couples where the wealth gap between household partners was the smallest in low-wealth households where the women had control over money management (Grabka et al. 2013).

Our findings about the effects of MFI credit on women's empowerment show that women gained decision-making power on issues pertaining to both their practical and strategic gender needs. The results also indicate that women with more strategic power are more likely to have access to MFI credit. This is because empowered women can efficiently invest their money and make a profit without the interference of their husbands nor any other family members and relatives. Hence, in the case presented in this paper, women's empowerment as a result of having access to and benefitting from microfinance could lead to "change in the structures of patriarchy" (Kabeer 2005: 16). We did not find evidence of pseudo-empowerment or the women-disempowering effect as reported elsewhere (Kabeer 2001; Armendàriz and Roome 2008). The results highlight the potential of MFIs as a tool for development. In her discussion about the importance of women's empowerment and development Kabeer (2005) underlines the role of resources through which agency can be exercised and empowerment attained. MFIs provide access to financial resources and enable women to generate new resources and assets. Therefore, the promotion of MFIs should be taking into account in the strategic plans of governments that address the contribution of women to development. In Côte d'Ivoire, this line is followed. Women's access to credit has become a priority in national policies and special funds are released to support women's income-generating activities, including the Support Fund for Women of Côte d'Ivoire (FAFCI). The fund aims to facilitate women's access to credit, especially for the poorest women, through microfinance institutions that use low-interest rates. To date, many women have benefited from this fund. Such opportunities will help women to generate income, support their families and contribute to their own empowerment, provided the credit is effectively used and the institutions are properly managed. These results are in line with the ones obtained by Holvoet (2005) for South India and Kabeer (2001) for rural Bangladesh in their empirical research on empowerment of women and MFI.

Open Access This article is distributed under the terms of the Creative Commons Attribution License which permits any use, distribution, and reproduction in any medium, provided the original author(s) and the source are credited.

\section{Appendix}

See Table 5 . 
Table 5 Factor loadings from principal component analysis on women's decision-making power before taking MFI credit

\begin{tabular}{lll}
\hline & $\begin{array}{l}\text { Factor 1 } \\
\text { Practical gender } \\
\text { needs }\end{array}$ & $\begin{array}{c}\text { Factor 2 } \\
\text { Strategic gender } \\
\text { needs }\end{array}$ \\
\hline $\begin{array}{ll}\text { Who makes decisions to use household consumption goods } \\
\text { Who makes decisions to use household income }\end{array}$ & $\frac{0.803}{0.808}$ & 0.132 \\
Who makes decisions for schooling of boys & $\underline{0.860}$ & 0.120 \\
Who makes decisions for schooling of girls & $\underline{0.848}$ & 0.054 \\
Who makes decisions about household equipment expenses & $\underline{0.771}$ & 0.055 \\
Who makes decisions for women's participation in & $\underline{0.721}$ & 0.185 \\
community activities & 0.092 & 0.159 \\
Who makes decisions to borrow money & 0.082 & $\underline{0.760}$ \\
Who makes decisions about the trade of goods & 0.168 & $\underline{0.792}$ \\
Who makes decisions to use the woman's income &
\end{tabular}

KMO: 0.80 [KMO (Kaiser-Meyer-Olkin) measures the sampling adequacy for a satisfactory factor analysis. With $\mathrm{KMO}=0.80$, we can say that factor analysis in this study was appropriate]; explained variance: $64.7 \%$; rotation method: Varimax (The Varimax rotation method assumes the independence between the factors. However, we first conducted factor analysis with oblimin rotation to check whether factors were related. Although we found a correlation coefficient $r=0.387$, in order to proceed with uncorrelated factors in subsequent analyses we used the uncorrelated factor solution) with Kaiser normalisation; coefficients higher than 0.5 underlined

\section{References}

ADB. (2000). Finance for the poor: Microfinance development strategy. Bangkok: Asian Development Bank.

Agarwal, B. (1997). 'Bargaining' and gender relations: Within and beyond the household. Feminist Economics, 3(1), 1-51.

Ali, A., \& Niehof, A. (2007). Changing gender roles in household food security. In R. Ruben, J. Pender, \& A. Kuyvenhoven (Eds.), Sustainable poverty reduction in less-favored areas (pp. 228-248). Wallingford: CAB International.

Amin, S., Rai, A. S., \& Ropa, G. (2003). Does microcredit reach the poor and vulnerable? Evidence from northern Bangladesh. Journal of Development Economics, 70, 59-82.

Armendàriz, B., \& Morduch, J. (2005). The economics of microfinance. Cambridge, MA: MIT Press.

Armendàriz, B., \& Roome, N. (2008). Empowering women via microfinance in fragile states. Université Libre de Bruxelles. CEB Working Paper 08/001.

Bauer, M., Chytilová, J., \& Morduch, J. (2012). Behavioural foundations of microcredit: Experimental and survey evidence from rural India. American Economic Review, 102(2), 1118-1139.

Binaté Fofana, N. (2010). Efficacy of micro-financing women's activities in Côte d'Ivoire: Evidence from rural areas and HIV/AIDS-affected women. [AWLAE Series no. 8] Wageningen: Wageningen Academic Publishers.

Buckley, G. (1997). Microfinance in Africa: Is it either the problem or the solution? World Development, 25(7), 1081-1093.

Chua, R. T., Mosley, P., Wright, G. A. N., \& Zaman, H. (2000). Microfinance, risk management, and poverty: Synthesis study. USAID, Washington, DC: Management Systems International.

Cleaver, F., \& Hamada, K. (2010). 'Good' water governace and gender equity: A troubled relationship. Gender and Development, 18(1), 27-41.

Coleman, B. E. (2006). Microfinance in northeast Thailand: Who benefits and how much? World Development, 34(9), 1612-1638. 
Conway, J. M., \& Huffcutt, A. I. (2003). A review and evaluation of exploratory factor analysis practices in organizational research. Organizational Research Methods, 6(2), 147-168.

Cornhiel, S. L. (2006). Feminization of agriculture: Trends and driving forces. Background paper for the World Development Report 2008.

Diagne, A. (1998). Impact of access to credit on income and food security in Malawi. FCND discussion paper 46. Washington, DC: Food Policy Research Institute (IFPRI).

Ellis, F. (2000). Rural livelihoods and diversity in developing countries. Oxford: Oxford University Press.

FAO. (1999). Gender issues in land tenure. In Paper prepared by the sustainable development Department, FAO for the UN high level consultation on rural women and information, Rome 4-6 October 1999.

FAO. (2000). IFAD's gender strengthening programme for East and Southern Africa-Uganda field diagnostic study. Rome: FAO.

FAO. (2005). The state of food and agriculture. FAO Agriculture Series No. 36, Rome.

Fischhoff, B. (1980). For those condemned to study the past: Heuristics and biases in hindsight. In D. Kahneman, P. Slovic, \& A. Tversky (Eds.), Judgment under uncertainty: Heuristics and biases (pp. 335-351). Cambridge: Cambridge University Press.

Garikipati, S. (2008). The impact of lending to women on household vulnerability and women's empowerment: Evidence from India. World Development, 36(12), 2620-2642.

Goetz, A. M., \& Gupta, R. S. (1996). Who takes the credit? Gender, power, and control over loan use in rural credit programs in Bangladesh. World Development, 24(1), 45-63.

González de la Rocha, M. (1994). Household headship and occupational position in Mexico. In E. Kennedy, \& M. González de la Rocha (Eds.), Poverty and well-being in the household: Case studies of the developing world (pp. 1-24). San Diego: Center for Iberian and Latin American Studies, University of California San Diego.

Grabka, M. M., Marcus, J., \& Sierminska, E. (2013). Wealth distribution within couples. Review of Economics of the Household, 11(4). doi:10.1007/s11150-013-9229-2.

Greeley, M. (2003). Poverty reduction and microfinance assessing performance. IDS Bulletin, 34(4), $10-20$.

Heckman, J. (1979). Sample selection bias as a specification error. Econometrica, 47, 153-161.

Holvoet, N. (2005). Credit and women's group membership in South India: Testing models of intrahousehold allocative behaviour. Feminist Economics, 11(3), 27-62.

Hulme, D. (1991). The Malawi Mudzi fund: Daughter of Grameen. Journal of International Development, 3(4), 427-432.

Hulme, D. (2000). Is microdebt good for poor people? A note on the dark side of microfinance. Small Enterprise Development, 11(1), 26-28.

Hulme, D., \& Mosley, P. (1996). Finance against poverty (Vol. 2). London: Routledge.

Institut National de la Statistique. (2008). Récensement général de la Population de Côte d'Ivoire. INS: Abidjan.

Johnson, S., \& Kidder, T. (1999). Globalization and gender-dilemmas for microfinance organizations. Small Enterprise Development, 10(3), 4-15.

Kabeer, N. (2001). Conflicts over credit: Re-evaluating the empowerment potential of loans to women in rural Bangladesh. World Development, 29(1), 63-84.

Kabeer, N. (2005). Gender equality and women's empowerment: A critical analysis of the third millennium development goal. Gender and Development, 13(1), 13-24.

Karim, L. (2001). Politics of the poor? NGOs and grass-roots political mobilization in Bangladesh. Political and Legal Anthropology Review, 24(1), 92-107.

Khandker, S. (2003). Microfinance and poverty: Evidence using panel data from Bangladesh. The World Bank Economic Review, 19(2), 263-286.

Khandker, S., Khalily, B., \& Khan, Z. (1995). Grameen bank: Performance and sustainability. World Bank discussion paper 306:162. Washington, DC: The World Bank.

Kremer, M., Lee, J., Robinson, J., \& Rostapshova, O. (2013). Behavioural biases and firm behaviour: Evidence from Kenyan retail shops. American Economic Review: Papers Proceedings, 103(3), $362-368$.

Laier, J. K. (1997). Women's work and the household in Latin America: A discussion of the literature. Working paper No. 97, Center for Development Research, Copenhagen.

Leete, L., \& Bania, N. (2010). The effect of income shocks on food insufficiency. Review of Economics of the Household, 8, 505-526. 
Mayoux, L. (1999). Questioning virtuous spirals: Micro-finance and women's empowerment in Africa. Journal of International Development, 11, 957-984.

McIntosh, G. (2008). Estimating treatment effects from spatial policy experiments: An application to Ugandan microfinance. The Review of Economics and Statistics, 90(1), 15-28.

Microcredit Summit Campaign Report. (2005). Washington, DC.

Moll, H. A. J. (2005). Microfinance and rural development: A long-term perspective. Journal of Microfinance, 7(2), 13-31.

Molyneux, M. (1985). Mobilization without emancipation? Women's interests, the state and revolution in Nicaragua. Feminist Studies, 11(2), 227-254.

Morduch, J. (1999). The microfinance promise. Journal of Economic Literature, 37, 1569-1614.

Morduch, J., \& Haley, B. (2002). Analysis of the effects of microcredit on poverty reduction. Working Paper No. 1014. New York: New York University Wagner.

Moser, C. O. N. (1989). Gender planning in the third world: Meeting practical and strategic gender needs. World Development, 17(11), 1799-1825.

Moser, C. O. N. (1993). Gender planning and development theory. New York: Routledge.

Mosley, P. (2001). Microfinance and poverty in Bolivia. Journal of Development Studies, 37(4), 101-132.

Mosley, P., \& Rock, J. (2004). Microfinance, labor markets and poverty in Africa: A study of six institutions. Journal of International Development, 16(3), 467-500.

Niehof, A. (2007). Fish and female agency in a Madurese fishing village in Indonesia. Moussons, 11, 185-209.

Pitt, M. M., \& Khandker, S. (1998). The impact of group-based credit programs on poor household in Bangladesh: Does the gender of participants matter? Journal of Political Economy, 106(5), 958-977.

Rahman, A. (1999). Micro-credit initiatives for equitable and sustainable development: Who pays? World Development, 27(1), 67-82.

Rahman, A. (2004). Microcredit and poverty reduction: Trade-off between building institutions and reaching the poor. In H. Lont \& O. Hospes (Eds.), Livelihood and microfinance: Anthropological and sociological perspectives on savings and debt (pp. 27-42). Delft: Eburon Academic Publishers.

Ravallion, M., Chen, S., \& Sangraula, P. (2007). New evidence on the urbanization of global poverty. Population and Development Review, 33(4), 667-701.

Rogaly, B. (1996). Micro-finance evangelism, destitute women and the hard selling of a new antipoverty formula. Development in Practice, 6(2), 100-112.

Rosenbaum, P. R., \& Rubin, D. B. (1983). The central role of the propensity score in observational studies for causal effects. Biometrika, 70(1), 41-55.

Sebstad, J., \& Chen, G. (1996). Overview of studies on the impact of microenterprise credit. Washington, DC: Management Systems International.

Simanowitz, A. (2004). Issues in designing effective microfinance impact assessment system. Imp-Act Working paper 8, Brighton: IDS.

Skoufias, E. (2001). Is PROGRESA working? FCND briefs 118. Washington, DC: International Food Policy Research Institute (IFPRI).

Tedeschi, G. A. (2008). Overcoming selection bias in microcredit impact assessments: A case study in Peru. Journal of Development Studies, 44(4), 504-518.

Tesfay, G. B. (2009). Econometric analyses of microfinance credit group formation, Contractual risks and welfare impacts in northern Ethiopia. Ph.D. Thesis, Wageningen University, Wageningen.

Todd, H. (1996). Women at the Center. Boulder, CO: West View Press.

Todd, P. E. (2008). Evaluating social programs with endogenous program placement and selection of the treated. In T. P. Schulz \& J. A. Strauss (Eds.), Handbook of development economics (Vol. 4, pp. 3847-3894). Amsterdam: Elsevier.

Udong, E., Niehof, A., \& Van Tilburg, A. (2010). The livelihood strategies of women fish traders in adapting to cultural and institutional constraints in Ibaka, Nigeria. Maritime Anthropological Studies, 9(2), 65-93.

UNDP. (1997). Human development report. New York: UN.

UNDP. (2012). Human development report. New York: UN.

Van Maanen, G. (2004). Microcredit: Sound business or development instrument? Hoevelaken: SGO Uitgeverij.

White, J., \& Robinson, E. (2000). HIV/AIDS and rural livelihood in Sub-Saharan Africa. Policy Series 6. Greenwich: Natural Resources Institute, University of Greenwich. 
Whitehead, A., \& Kabeer, N. (2002). Living with uncertainty: Gender, livelihoods and pro-poor growth in rural sub-Saharan Africa. Working Paper 134. Brighton: Institute of Development Studies.

World Bank. (2007). Global monitoring report: Confronting the challenges of gender equality and fragile states. Washington, DC: The World Bank.

Zaman, H. (2004). The scaling-up of microfinance in Bangladesh: Determinant, impacts and lessons. World Bank Policy Research Working Paper No. 3398. Washington, DC: The World Bank. 